\title{
ANALISIS VISUAL SAMPUL MAJALAH "BOBO" EDISI BULAN APRIL 2016
}

\author{
Ni Nyoman Sri Witari dan Ketut Nala Hari Wardana \\ Program Studi Desain Komunikasi Visual \\ Fakutas Bahasa dan Seni \\ Universitas Pendidikan Ganesha, Singaraja \\ e-mail: sri.witari@undiksha.ac.id dan nala.hari@undiksha.ac.id
}

\begin{abstract}
Bobo Magazine is one of children's magazine which is still exsisted from 1974 until now. Their cover has its own uniqueness. This research was aimed at identifying visual layout of Bobo Magazine, finding the quality of element's design and visuals elements.

The research method is qualitative approach which are collected from observation results, documentation and library research. The object of research was Bobo's magazine cover of April edition, 2016. The data analysis used to analyze visualization quality was the theory of Tom Lincy about five principal design on printed works, such as proportion, balance, contrast, rhyme, and unity. From the visual data analysis it was found that layout composition from illustration, texts/letter, and colour on cover has applied the principles of unity, balance, rhyme, contrast and proportion. The visual's fascination is unique, different from others, because it was supported by the use of Bobo's family characters as icons, the use of bright pastel colours, the use of exact San Serif letters and dynamic layout of objects.
\end{abstract}

Keywords: magazine cover, visual quality, design principles

\begin{abstract}
ABSTRAK
Majalah Bobo adalah salah satu majalah anak-anak yang hingga kini masih tetap eksis sejak tahun 1974. Sampul mukanya mempunyai daya tarik tersendiri. Penelitian ini bertujuan untuk mengidentifikasi tampilan visual majalah Bobo, menemukan kualitas penerapan prinsip-prinsip desain pada unsur-unsur visualnya.

Metode penelitian ini menggunakan pendekatan kualitatif, dengan data yang dikumpulkan dari hasil observasi, dokumentasi, dan kepustakaan. Obyek penelitian ini adalah sampul muka majalah Bobo edisi bulan April 2016. Analisis data yang digunakan untuk menganalisis kualitas visualisasinya adalah teori desain Tom Lincy tentang lima prinsip desain pada karya cetak yaitu proporsi, keseimbangan, kontras, irama, dan kesatuan. Dari hasil analisis data visual diperoleh bahwa komposisi layout dari ilustrasi, teks/ huruf, dan warna pada sampul muka majalah Bobo memang sudah menerapkan prinsip kesatuan (unity), keseimbangan (balance), irama (ritme), kontras, dan proporsi. Daya tarik visualnya mengandung kesan unik lain daripada yang lain karena ditunjang oleh penggunaan karakter keluarga Bobo kelinci sebagai ikonnya, penggunaan warna warni pastel yang ceria, penggunaan jenis huruf Sans Serif yang tepat dan tata letak objek yang dinamis.
\end{abstract}

Kata kunci: sampul majalah, kualitas visual, prinsip-prinsip desain. 


\section{PENDAHULUAN}

Majalah adalah salah satu media publikasi yang bisa dipergunakan sebagai sumber pengetahuan. Membaca majalah akan memberikan tambahan wawasan dan perspektif tentang suatu informasi. Majalah juga bisa menjadi sumber hiburan yang menarik karena mengandung cerita dengan gaya bahasa yang menarik, ilustrasi yang indah, kuis dengan bermacam hadiah, rubrik pertemanan, informasi tentang lagu, film atau artis kesayangan, bermacam-macam hobi unik, dan sebagainya. Sebagai salah satu majalah anak-anak yang mempunyai eksistensi yang stabil dari waktu ke waktu selama puluhan tahun, majalah Bobo merupakan salah satu majalah yang mempunyai kualitas isi seperti yang disebutkan di atas.

Sebagai majalah khusus anak-anak sampul majalah Bobo memiliki tampilan visual yang atraktif. Ikon Bobo kelinci dan keluarganya terlihat begitu hidup, ceria, dan bersahabat. Sampul majalah ini tampak begitu berbeda dengan sampul majalah anakanak lainnya. Jika dikaitkan dengan psikologi persepsi, karakteristik sampul majalah Bobo mampu menumbuhkan sensasi positif kepada anak-anak yang melihatnya. Sensasi yang dimaksudkan di sini adalah pengalaman elementer yang segera, yang tidak memerlukan penguraian verbal, simbolis, atau konseptual, dan terutama sekali berhubungan dengan kegiatan alat indra menurut Benyamin B. Wolman (1973:343) dalam Jalaludin Rakhmat (2007:55). Sehingga sangat besar kemungkinannya bahwa melalui indera penglihatannya, anak-anak yang melihat sampul muka majalah Bobo dapat segera menyadari kualitas informasi yang akan didapatnya pada majalah tersebut.

Asumsi di atas bukan tanpa alasan, karena berdasarkan beberapa penelitian tentang majalah Bobo menunjukkan kesimpulan betapa keunggulan kontennya sangat memengaruhi pembacanya. Berikut beberapa penelitian yang membahas majalah Bobo. Pertama, penelitian Fatwa Amalia (2013) yang berjudul "Kajian Nilai Moral Cerita Pendek
Pada Majalah Bobo Sebagai Upaya Pemilihan Bahan Ajar Apresiasi Sastra di Kelas Tinggi Sekolah Dasar", mengkaji nilai moral dari delapan cerita pendek pada Majalah Bobo terbitan Januari-Desember 2011 dengan menggunakan pendekatan strukturalisme dari Robert Stanton (http://repository. upi.edu/ id/eprint/1643). Hasil penelitian ini menyebutkan bahwa tema cerita Bobo mengangkat tentang usaha untuk menolong orang lain, usaha untuk mendapatkan sesuatu, dan berbagi dengan sesama. Peneliti menemukan ada lima nilai moral yang terkandung yaitu: 1) kejujuran; 2) kesediaan untuk bertanggungjawab 3) kemandirian moral, 4) keberanian moral; 5) serta realistis dan kritis dan lain-lain. Kedua, artikel Ayu Puspita Indah Sari (2015) "Nilai Moral Pada Cerpen Hujan Terakhir Majalah Bobo Sebagai Media Pembentukan Karakter Siswa Sekolah Dasar" menyatakan bahwa cerpen Hujan Terakhir pada majalah Bobo secara struktural mempunyai nilai edukasi yang sangat tinggi. Nilai moral yang terdapat di dalamnya adalah nilai religius dan nilai sosial yang berupa kejujuran, disiplin, tanggung jawab, toleransi, gotong royong, santun, dan percaya diri.

Kedua tulisan di atas meneliti tentang muatan nilai-nilai positif yang terkandung pada konten cerita majalah Bobo. Keduanya membahas dari sisi struktur kebahasaan. Sementara penelitian yang menyangkut tampilan visual majalah Bobo masih belum banyak dipublikasikan. Padahal jika diobservasi lebih mendalam, unsur visual juga merupakan aspek yang sangat berpengaruh terhadap tumbuhnya respon atau minat seseorang untuk membaca objek yang dilihatnya. Demikian pula halnya dengan minat membaca majalah Bobo pada seorang anak tidak bisa dilepaskan dari peran tampilan visual sampul majalah Bobo yang menarik.

Dari latar belakang yang diuraikan ada satu permasalahan yang diangkat pada tulisan ini sebagai hasil penelitian mendalam tentang tampilan visual sampul majalah Bobo yakni tentang kualitas tampilan visual sampul majalah Bobo dari sudut prinsip-prinsip desain, terutama desain dari sisi Desktop 
Publishing yang meliputi prinsip proporsi, keseimbangan, irama, kontras, dan kesatuan.

Sebagai sebuah produk komunikasi visual, desain sampul majalah terdiri dari susunan elemen-elemen visual seperti ilustrasi, teks/tipografi, warna dan komposisi layout/ tata letak. Ilustrasi adalah seni gambar yang dimanfaatkan untuk memberi penjelasan atas suatu maksud atau tujuan secara visual. Ilustrasi itu bisa dibuat dengan beragam teknik, seperti woodcut atau mencukil relief pada kayu kemudian dicap pada kertas atau kain, teknik fine art, fotografi (Kusriyanto 2007:140). Pada umumnya ilustrasi sampul muka majalah anak-anak dikenal ada dua jenis ilustrasi yaitu ilustrasi kartun dan realis. Ilustrasi kartun biasanya merujuk pada suatu bentuk tanggapan lucu dalam citra visual (Noerhadi, 1989:189). Gambar realis merupakan ikon yang paling mirip dengan manusia atau obyek aslinya (McCloud, 2001:29).

Teks adalah huruf yang disusun atau distrukturkan dengan cara-cara tertentu sehingga bisa dibaca seperti halnya teks pada sebuah buku (Burton, 2008:33). Pada konteks desain grafis teks ditulis dengan huruf (font) yang mempunyai karakter tertentu. Untuk panduan penggunaan huruf dikenal ilmu khusus yang mengulik tentang huruf yang disebut tipografi. Secara tradisional istilah tipografi berkaitan dengan setting huruf dan pencetakannya (Rustan, 2010: 16).

Sanyoto (2009:13), secara ilmiah warna didefinisikan sebagai getaran gelombang yang diterima oleh indra penglihatan. Warna juga merupakan sifat cahaya yang dipancarkan (objektif) atau sebagai bagian dari pengalaman indra penglihatan (subjektif). Menurut Molly E. Holzschlag (dalam Kusrianto, 2007:47) warna dapat memberikan respon psikologis, diantaranya warna merah memberi respon psikologis kekuatan, bertenaga, kehangatan, nafsu, cinta, agresivitas, dan bahaya. Kuning Optimis, harapan, filosofi, ketidakjujuran/kecurangan, pengecut, pengkhianatan.

Efektif atau tidaknya suatu media cetak ditentukan oleh dua hal yaitu kualitas tampilan komposisi layout/tata letak dan isi (konten).
Sebuah majalah harus ditata tampilannya dengan susunan yang menarik supaya informasi yang dimuat bisa diterima dengan baik oleh pembacanya. Namun demikian, komposisi layout atau tata letak suatu majalah tidak mempunyai aturan yang baku. Konsep dalam buku "breaking the rule" karya desainer Thailand -Supon Phornirunlit - tentang desain tidak beraturan merupakan keniscayaan yang juga mampu menghasilkan karya desain yang bagus.

Terlepas dari kebebasan berekspresi dalam mendesain sampul majalah, maka Tom Lincy dalam Design Principle for Desktop Publishing memastikan bahwa ada lima prinsip utama yang dipergunakan sebagai acuan ketika seorang desainer berkarya (Kusrianto, 2007: 277-285).

1. Proporsi (proportion) yaitu kesesuaian antara ukuran halaman dengan isinya.

2. Keseimbangan (balance) yaitu suatu pengaturan dalam suatu halaman memiliki efek seimbang, baik yang informal maupun formal. Seimbang bukan berarti sama besar, namun lebih bermakna memiliki tampilan yang sama bobotnya. Penerapan prinsip ini berhubungan dengan kesatuan dan harmoni.

3. Kontras (contrast) yaitu adanya kombinasi antara dua unsur yang berbeda sehingga menimbulkan efek penonjolan pada salah satu unsurnya. Jika suatu desain menampilkan elemen-elemen yang sama kuatnya maka akhirnya tidak ada satu pun materi dari halaman itu yang menonjol. Hal seperti ini dapat menggagalkan misi yang ingin difokuskan dari desain yang dibuat.

4. Irama (rhythm) yaitu memiliki kesamaan makna dengan repetisi atau pola pengulangan yang diharapkan menimbulkan irama yang menarik dinikmati.

5. Kesatuan (unity) atau sama dengan kedekatan (proximity) adalah hubungan antara elemen-elemen desain yang semula berdiri sendiri serta memiliki ciri sendiri-sendiri yang disatukan menjadi suatu yang baru dan memiliki fungsi baru yang utuh.

Kelima prinsip inilah yang dipergunakan sebagai acuan untuk menilai kualitas sebuah desain yang komunikatif. 


\section{METODE}

Penelitian ini merupakan penelitian kualitatif yang ingin mendeskripsikan kualitas tampilan visual sampul muka majalah Bobo. Objek penelitian ini adalah sampul muka majalah Bobo yang terbit pada bulan April 2016 yang terdiri dari lima edisi. Jenis data yang diperoleh adalah data primer dan sekunder melalui metode observasi, dokumentasi, dan studi kepustakaan.

Sampel objek penelitian adalah sampul muka majalah Bobo yang terbit pada bulan April tahun 2016 dengan teknik sampling purposive sampling, dimana objek penelitian secara sengaja dipilih (bulan April) untuk memudahkan pengkodifikasian di mana bulan April merupakan penomoran awal penerbitan majalah Bobo dalam durasi volume pertahun. Analisis data dilakukan dengan mendeskripsikan kualitas tampilan visual sampul majalah Bobo dari kesesuaian komposisi ilustrasi, teks/ tipografi, warna, yang sesuai dengan menggunakan pendekatan lima prinsip desain menurut Tim Lincy (Kusrianto, 2007:277).

Tabel 1. Lima prinsip desain menurut Tim Lincy (Kusrianto, 2007:277).

\begin{tabular}{|l|l|l|}
\hline No. & $\begin{array}{c}\text { Unsur Visual } \\
\text { Sampul } \\
\text { Majalah Bobo }\end{array}$ & \multicolumn{1}{|c|}{$\begin{array}{c}\text { Prinsip Desain } \\
\text { (Tom Lincy) }\end{array}$} \\
\hline 1 & Ilustrasi & $\begin{array}{l}\text { a. proporsi, } \\
\text { b. keseimbangan, } \\
\text { c. kontras, } \\
\text { d. irama, } \\
\text { e. kesatuan }\end{array}$ \\
\hline 2 & Teks/Tipografina \\
\hline 3 & Warna & \\
\hline
\end{tabular}

Dari hasil analisis kualitas komposisi layout/tata letak ketiga unsur visual majalah Bobo, peneliti dapat menyimpulkan kualitas tampilan desain sampul muka majalah Bobo menurut kaidah-kaidah desain untuk media publikasi massa.

\section{HASIL DAN PEMBAHASAN}

\section{Metamorfosis Tampilan Visual Sampul Majalah Bobo Sebelum Tahun 2016}

Sebagaimana lazimnya sebuah majalah, Bobo mempunyai keunikan dalam tampilan visualnya. Secara visual majalah Bobo mempunyai penampilan yang atraktif sesuai dengan karakteristik pembacanya yang menyasar kalangan anak-anak sekolah dasar. Bobo secara konsisten menampilkan sampulsampul yang menarik serta selalu memberi gambaran tentang tema yang diangkat pada edisi yang bersangkutan. Hal ini dapat dicermati selama penerbitan lima tahun terakhir. Sebagai bukti bahwa konsistensi Bobo memang kuat, dapat dicermati dari metamorfosis majalah Bobo dari tahun 70-an hingga lima tahun terakhir (2011 - 2015) sebagaimana yang ditunjukkan pada contoh-contoh berikut ini
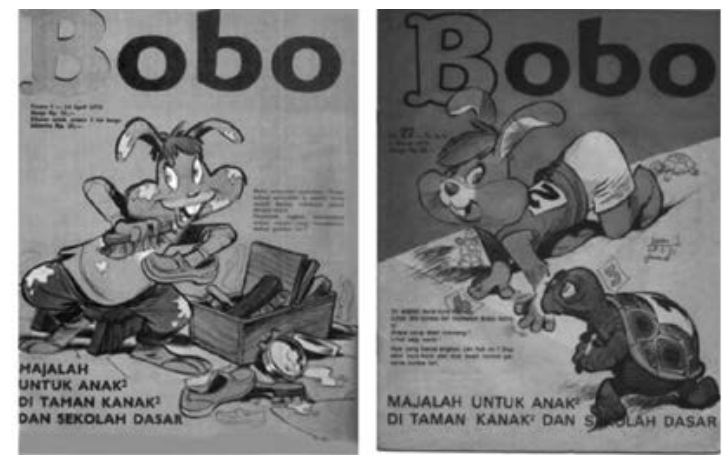

Gambar 1 dan 2. Contoh sampul majalah Bobo yang terbit tahun 70-an (Edisi tahun 1973-kiri dan tahun 1975-kanan).Sumber: http//www. tips-unik-dunia.blogspot.com
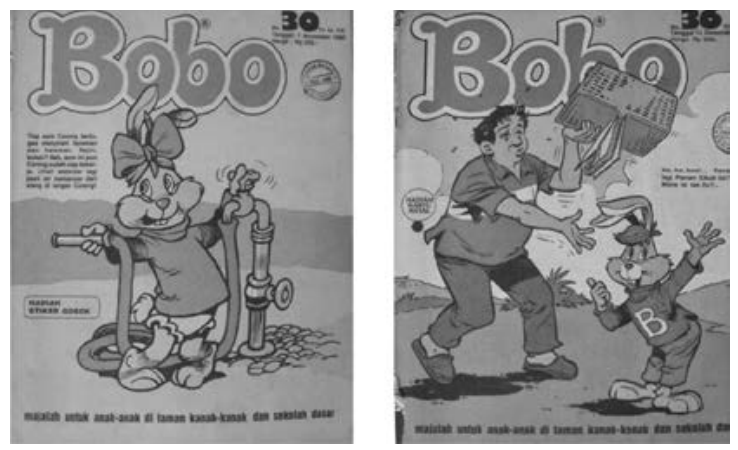

Gambar 3 dan 4. Contoh sampul majalah Bobo yang terbit tahun 80 -an edisi November 1980

(kiri ) dan tahun Desember 1980 (kanan).

Sumber: http//www.koleksitempodoeloe. blogspot.com` 

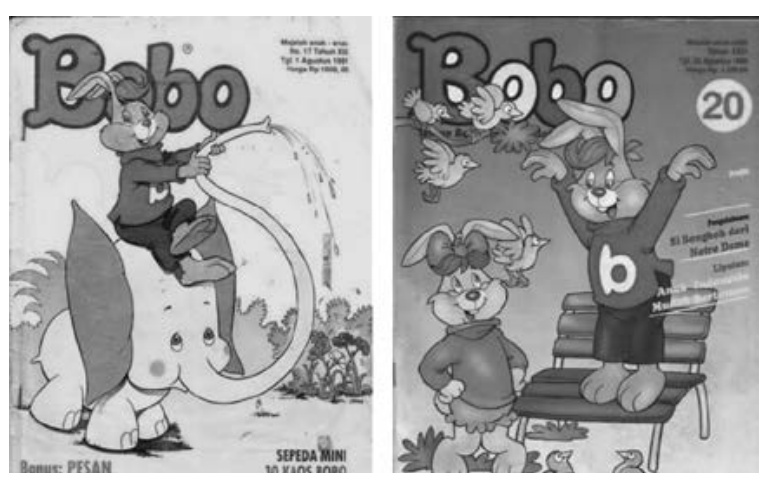

Gambar 5 dan 6. Contoh sampul majalah Bobo yang terbit tahun 90-an edisi tahun 1991 (kiri) dan tahun 1995 (kanan). Sumber: http//www. tips-unik-dunia.blogspot.com
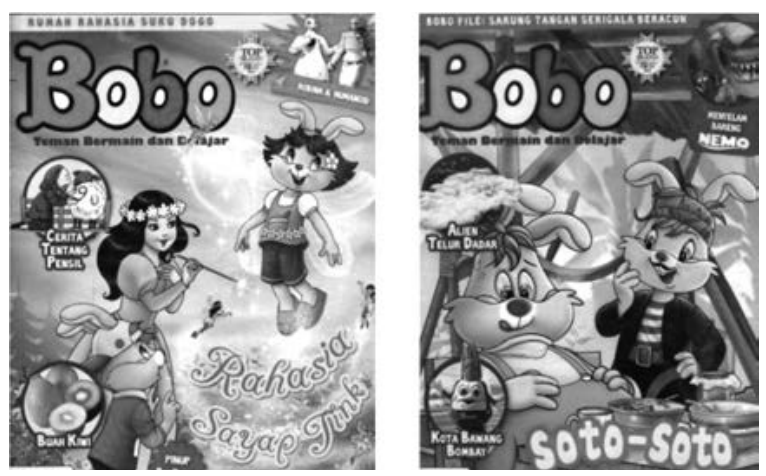

Gambar 7 dan 8. Contoh sampul majalah Bobo yang terbit tahun 2011 (kiri) dan 2012 (kanan).
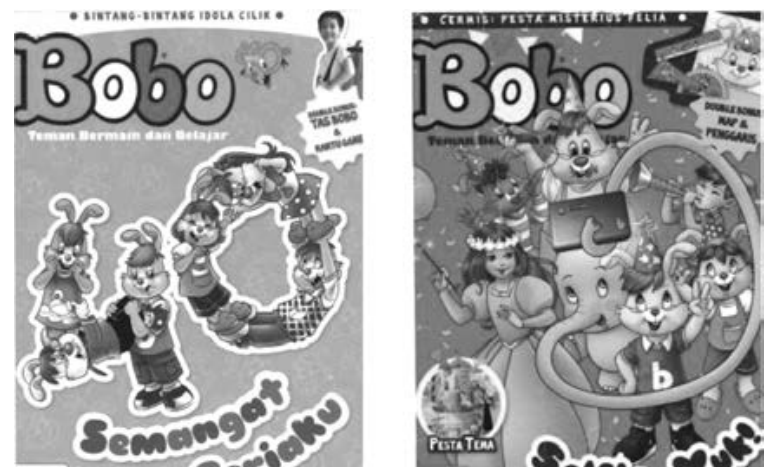

Gambar 9 dan 10. Contoh sampul majalah Bobo yang terbit tahun 2013 (kiri) dan 2014 (kanan).

Metamorfosis pada tampilan sampul majalah Bobo mengalami perubahan yang sangat menjolok di era 2000-an. Dibandingkan dengan tahun 1970-an sampai 1990-an, tampilan visual sampul majalah Bobo tahun 2000-an menunjukkan adanya perubahan yang sangat kompleks pada komposisi warna, ilustrasi, huruf dan tata letaknya. Figur tokoh-tokohnya juga mengalami perubahan pada tampilan tata busananya yang disesuaikan dengan kondisi busana di era 2000-an. Ilustrasi tokoh dibuat lebih detail dan halus. Perubahan yang signifikan dalam tampilan visual sampul majalah Bobo tidak lepas dari adanya sentuhan teknologi komputer grafis.

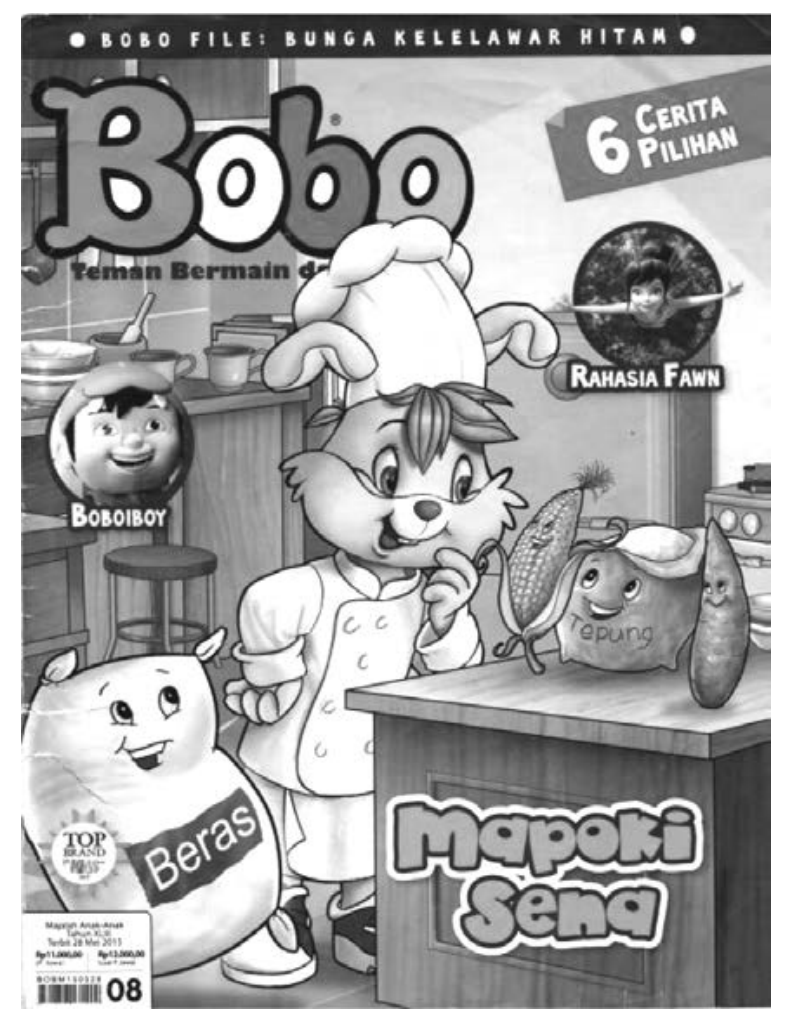

Gambar 11. Contoh sampul majalah Bobo yang terbit tahun 2015 yang diolah secara digital

Menurut Philip Meggs (dalam Couto, https//www.belanak.wordpress.com) komputer digital menjadi tempat desainer untuk melakukan berbagai improvisasi dalam kegiatan menciptakan huruf, menggabungkan images (foto-foto), menggambar dengan beragam warna yang kompleks. Sehingga layout yang dihasilkan jauh lebih bagus. Penggunaan teknologi digital ini menyebabkan tampilan visual majalah Bobo jauh lebih menarik. Jika dicermati lebih seksama, persamaan antara sampul era 1970-an awal hingga 2000-an sampul majalah Bobo adalah menampilkan pola yang konsisten. Gambar ilustrasi yang dipasang senantiasa menggambarkan topik utama yang diangkat pada edisi yang ber- 
sangkutan dan aktivitas yang dilakukan menunjukkan situasi/trend pada masa itu. Karakter Bobo yang ditampilkan di setiap sampul selalu melakukan aktivitas permainan kreatif pada zaman yang bersangkutan. Misalnya ilustrasi pada sampul tahun 1970-an, tokoh Bobo melakukan kegiatan menyemir sepatu dan bermain lomba lari melawan kurakura. Sementara ilustrasi era 2000-an, karakter Bobo tampak sedang melakukan aktivitas sulap, jualan soto, main akrobat, dan lain-lain bersama kawan-kawannya. Perbedaan lain yang membedakan ilustrasi antara Bobo lama dan yang baru adalah pada pola busana yang dikenakan. Pada Bobo lama, busana karakter menggunakan pakaian aslinya, sedangkan pada Bobo baru busana yang dikenakan disesuaikan dengan topik aktivitas yang dilakukan. Misalnya mengenakan busana seragam tim pemadam kebakaran (lihat sampel pada gambar 12). Perbedaan lain yang signifikan adalah pada kualitas tampilan warna dan huruf. Perbedaan ini disebabkan karena tingkat teknologi grafis yang berbeda. Pada era 1970-an, belum dikenal grafis digital sehingga pilihan warna dan huruf masih sangat terbatas.

\section{Tampilan Visual Sampul Muka Majalah Bobo Edisi April 2016}

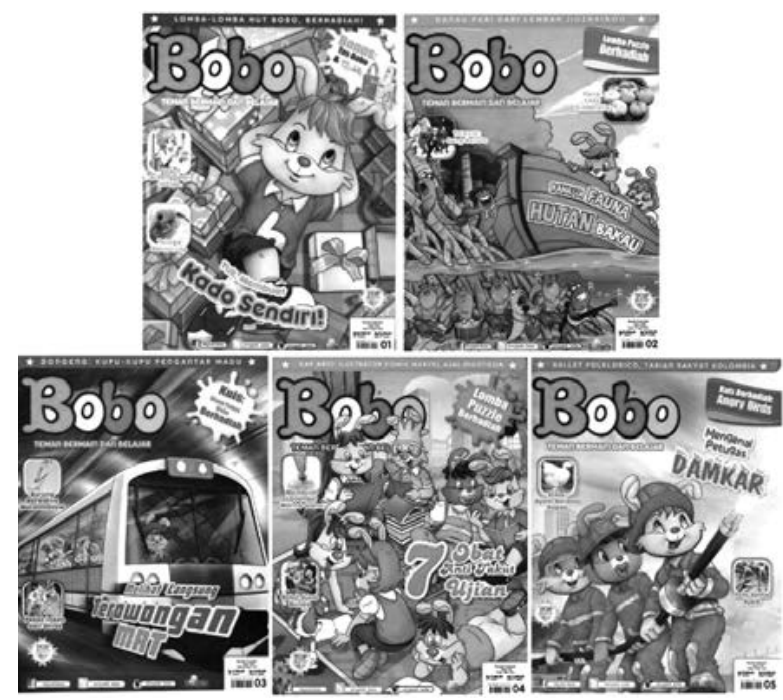

Gambar 12. Tampilan visual lima sampel penelitian sampul majalah Bobo edisi 01, 02, 03,

04, 05, yang terbit pada bulan April 2016.

Majalah Bobo yang dipakai sebagai bahan penelitian ini adalah edisi $01-05$ tahun 2016. Secara visual sampul muka majalah Bobo mempunyai elemen-elemen desain yang terdiri atas teks, font (huruf), ilustrasi, dan warna yang di-layout dengan menggunakan prinsip-prinsip proporsi, keseimbangan, kontras, irama, dan kesatuan (Tom Lincy dalam Kusrianto, 2007:27).

\section{Analisis Visual Sampul Majalah Bobo Edisi 2016 menurut Prinsip Proporsi, Keseim- bangan, Kontras, Irama, dan Kesatuan}

\section{a. Proporsi}

Dalam prinsip desain grafis, proporsi mempunyai pengertian perbandingan antara bagian dengan bagian dan antara bagian dengan keseluruhan (Kusrianto, 2007:43). Namun, dalam kaitannya dengan layout (tata letak) sebuah sampul majalah, proporsi yang dimaksud adalah kesesuaian antara ukuran halaman dengan isinya. Untuk sampul majalah Bobo ukuran bidangnya adalah 21 x 27,5 $\mathrm{cm}$. Ukuran ini mendekati ukuran letter $(21,59$ x 27,94 cm). Ukuran letter pada umumnya dipakai sebagai standar ukuran siap pakai di hampir semua program aplikasi dan disinyalir mempunyai 'power' tersembunyi dalam ilmu tata letak, sehingga hampir semua buku menggunakan proporsi bidang kertas yang seukuran letter (Kusrianto, 2007:277).

Proporsi pada ilustrasi. Untuk sampul majalah Bobo, proporsi ukuran $21 \times 27,5$ dipergunakan secara fullpage oleh gambar/ilustrasi. Tidak ada unsur ruang yang tanpa ilustrasi dan warna. Ilustrasi mendominasi hampir semua bidang.

Proporsi pada warna. Hampir setiap bagian pada sampul majalah Bobo berwarna (fullcolour). Proporsi warna didominasi oleh warna-warni pastel yang cerah yang menghasilkan nuansa ceria sesuai psikologis anakanak.

Proporsi pada teks dan huruf. Teks ditata sedemikian rupa sehingga mudah dibaca dan dimengerti. Proporsi setiap teks disesuaikan ukuran dan pilihan karakter hurufnya sesuai hierarki fungsinya pada sampul. Misalnya untuk judul majalah dibuat jauh lebih 
besar dan paling menonjol dari segi ukuran. Sementara untuk sub judul dibuat lebih kecil dan posisinya lebih di bawah. Jenis huruf yang dipilih rata-rata mempunyai bentuk yang sans serif dan naif sesuai karakter anak-anak yang lucu dan polos.

\section{b. Keseimbangan (balance)}

Prinsip keseimbangan merupakan suatu pengaturan agar penempatan elemen dalam suatu halaman memiliki efek seimbang. Terdapat dua macam keseimbangan yaitu formal (simetris) dan informal (asimetris). Keseimbangan formal digunakan untuk menata letak obyek agar rapi dan formal; sedangkan informal memiliki tampilan yang tidak simetri (Kusrianto, 2007:279).

Pada sampul majalah Bobo kedua prinsip keseimbangan ini dipergunakan. Seperti pada sampel 1,3,4 menggunakan prinsip keseimbangan formal (simetris) karena obyek (ilustrasi dan teks) diatur secara seimbang antara kiri kanan, atas dan bawah. Tidak terdapat ketimpangan atau aksen ruang yang lebih kosong dibandingkan bagian yang lain. Sedangkan keseimbangan informal diaplikasikan pada sampul sampel 2 dan 5. Pada kedua sampel ini tampak ada perbedaan kepadatan pada penempatan objek. Namun ketidakseimbangan ini bukan berarti menyebabkan adanya ketidakharmonisan; justru asimetri ini memberi kesan yang lebih meruang dan dinamis. Pada dasarnya semua elemen yang disusun pada sampul majalah Bobo mengandung unsur keseimbangan yang bagus, dengan bobot tampilan yang sama meskipun cara pengaturannya berbeda. Prinsip keseimbangan pada sampul Bobo menonjolkan dinamisnya dunia anak-anak, tanpa membatasi ruang gerak dan kreativitas mereka.

Keseimbangan pada ilustrasi. Ilustrasi merupakan unsur terpenting pada sampul Bobo. Ilustrasi yang menjelaskan setiap tema yang diangkat pada edisi yang bersangkutan. Ilustrasi juga yang menggambarkan isi majalah serta menciptakan ciri khas pada sampul Bobo. Prinsip keseimbangan diterapkan dengan seksama pada ilustrasi, sehingga bisa menjelaskan elemen-elemen lain tanpa mengurangi keterbacaannya.

Keseimbangan pada warna. Warnawarna yang diterapkan saling mengimbangi. Tidak tampak kesan ada warna dominan yang muncul mengatasi warna yang lain. Komposisinya ditata harmonis sehingga menghasilkan kombinasi warna yang cerah, ceria dan atraktif selayaknya citra anak-anak. Warna pada Bobo terdiri dari unsur warna primer, sekunder dan tersier. Namun kelompok warna ini mendapat nuansa tint (percampuran dengan putih) atau pastel sehingga berkesan lebih lembut sekaligus terang.

Keseimbangan pada teks/huruf. Pada tiap edisi, teks dan huruf pada sampul Bobo ditata dengan menyesuaikan pada ilustrasi. Teks yang saling menyeimbangkan satu sama lain adalah title (judul majalah) dan headline. Kadang menempati posisi lurus ke bawah, atau diagonal; bergantung pada alur ilustrasinya. Sedangkan teks dan huruf yang lain menyesuaikan.

\section{c. Kontras}

Kontras biasanya berhubungan dengan value gelap terang pada suatu objek gambar. Kontras value dalam Desain Komunikasi Visual biasanya digunakan dalam menonjolkan pesan atau informasi, sekaligus menciptakan citra tertentu (Supriyono, 2010:78). Yang tampak pada sampul majalah Bobo baik dari sampel 1-5 adalah adanya penggunaan kontras warna yang tinggi (high contrast value) meskipun pada dasarnya warna-warna yang diterapkan adalah warna bernuansa pastel yang harmonis. Komposisi warna yang kontras ini misalnya mendampingkan antara warna merah dengan biru, putih dengan merah muda atau hijau, sehingga menciptakan nuansa dinamis, enerjik, riang, bergairah dan sekaligus hangat.

Kontras pada ilustrasi. Unsur yang paling kontras pada ilustrasi adalah adalah selalu ada objek/tokoh yang paling menonjol ukurannya dibandingkan yang lain. Kecuali pada sampel 04, kondisi ini tidak berlaku. Selain ukuran yang kontras pada ilustrasi adalah detail objek atau aktivitas yang dilakukan. Kontras ini memberi nilai menguatkan tema 
yang disuguhkan pada edisi tersebut.

Kontras pada teks/huruf. Kontras teks/huruf pada sampul Bobo terletak pada judul majalah Bobo yang sengaja ditampilkan menggunakan empat warna yang berbeda yaitu biru, kuning, merah dan hijau serta diberi dasar putih. Kontras berikutnya adalah karena ukuran hurufnya yang paling besar diantara teks/huruf yang lain. Kontras pada teks Bobo ini sebagai penonjolan terhadap eksistensi dan fungsinya sebagai nama majalah anak-anak ini. Kontras lainnya dari unsur teks/huruf adalah adanya beragam gaya tata letaknya, terutama headline, yang sengaja dipasang secara berbeda (:miring/diagonal) dibandingkan teks lainnya.

\section{d. Irama (rhythm)}

Irama sebenarnya mempunyai makna sama dengan repetisi atau perulangan. Perulangan inilah yang menimbulkan adanya irama. Pengulangan biasanya terjadi pada penerapan pola warna maupun motif.

Irama pada ilustrasi. Majalah yang bertajuk Bobo ini melakukan pengulangan penggunaan tokoh Bobo dan keluarganya sebagai objek utama sekaligus menjadi ikonnya. Pengulangan ini menguatkan judul majalah, serta memberitahukan kepada anak-anak bahwa Bobo adalah tokoh utama dari majalah yang mereka baca.

Irama pada warna. Pengulangan warna tidak berlaku pada sampul majalah Bobo. Yang ada hanya menciptakan irama yang harmonis antara warna yang satu dengan yang lain.

Irama pada teks/huruf. Pada sampul majalah Bobo prinsip irama atau repetisi diterapkan pada penggunaan pilihan huruf. Satu jenis huruf digunakan secara berulang dan diterapkan dengan ukuran yang berbeda sesuai dengan hierarkinya.

\section{e. Kesatuan (Unity)}

Sebuah desain dapat disebut memiliki kesatuan jika secara keseluruhan tampak harmonis antara tipografi, ilustrasi, warna dan unsur-unsur desain yang lainnya. Elemen-elemen yang semula berdiri sendiri dapat disatukan menjadi sesuatu yang baru dan utuh serta mempunyai fungsi yang utuh.

Kesatuan pada ilustrasi. Pada sampul majalah Bobo prinsip kesatuan pada ilustrasi tergambar dari kesinambungan dan kelugasan bentuk yang mampu bercerita secara utuh tentang tema yang diangkat. Kesatuan pada unsur ilustrasi mampu memberi gambaran yang nyata sekaligus imajinatif kepada anak-anak yang membaca Bobo.

Kesatuan pada warna. Penyatuan beberapa jenis warna pada ilustrasi, teks dan elemen-elemen lainnya pada dasarnya bertujuan untuk menghasilkan harmonisasi agar sampul Bobo menjadi menarik dan sesuai dengan karakteristik anak-anak.

Kesatuan pada teks/huruf. Penggunaan maksimal tiga jenis huruf untuk headline, tagline dan subheadline, memudahkan dalam menciptakan kesatuan yang mampu menjelaskan urgensi dan fungsi masing-masing teks. Pilihan pada satu jenis huruf untuk kelompok tagline dan subline memberikan makna bahwa teks pada bagian tersebut memiliki posisi yang sejajar di dalam isi majalah. Pembaca bisa membedakan teks yang merupakan topik utama dan teks yang bersifat tetap setiap edisi.

\section{Ciri Khas Unsur-unsur Visual Sampul Ma- jalah Bobo}

Secara visual sampul majalah Bobo mempunyai tampilan visual yang menarik dan unik. Daya tariknya terletak pada kematangan dan keluwesan mengolah ruang vertikal (portrait) dengan komposisi layout yang harmonis antara teks dan ilustrasinya. Penggunaan warna pastel yang cerah dan berwarna-warni penuh harmoni memberi kesan atraktif dan sesuai dengan jiwa anak-anak yang ceria. Berdasarkan pengalaman dari eksistensi Bobo selama 42 tahun dan telah melewati fase cetak nondigital ke era digital, merupakan suatu jaminan untuk menunjukkan jati diri Bobo sebagai salah satu majalah anak-anak yang secara visual telah mapan secara grafis.

Sebagaimana diketahui bahwa komposisi adalah pengorganisasian unsur-unsur rupa yang disusun dalam karya desain grafis secara harmonis antara bagian dengan bagian, maupun antara bagian dengan keseluruhan (Kus- 
rianto, 2007:34). Kunci untuk menghasilkan sebuah karya grafis yang bagus adalah fokus terhadap masalah komposisi. Dengan demikian, dapat disimpulkan bahwa sampul majalah Bobo menjadi menarik salah satunya karena komposisinya yang harmonis. Kaidah-kaidah komposisi yang harmonis betul-betul diperhatikan dalam menata tampilan visualnya. Prinsip kesatuan (unity), keseimbangan (balance), irama (ritme), kontras, fokus (pusat perhatian) serta proporsi semuanya terakomodir dengan sangat baik pada majalah Bobo yang menjadi sampel penelitian. Komposisi yang dipergunakan juga senantiasa dinamis, kadang simetris dan sering juga asimetris; namun tetap harmonis.

Kekhasan pada unsur ilustrasi. Daya tarik visual majalah Bobo terletak pada penggunaan ilustrasi yang menarik dengan tokoh Bobo kelinci sebagai ikon utama. Sesuai dengan nama majalahnya-Bobo, yang merupakan tokoh utama pada cerita Bobo Kelinci, maka penggunaan ilustrasi tokoh Bobo kelinci merupakan unsur pembeda (distinctive) antara Bobo dengan majalah anak-anak yang lain.

Dalam desain komunikasi visual, ilustrasi akan menjadi pengikat perhatian bagi $a u$ dience. Beberapa keunggulan yang dipunyai oleh ilustrasi sampul Bobo hingga menggugah perasaan dan hasrat untuk membaca antara lain karena bentuk gambarnya komunikatif dengan garis gestur yang mudah dipahami; ide menggunakan karakter personifikasi manusia kelinci merupakan sebuah keunikan; finishing dan pewarnaan yang sangat detail terlebih dengan sentuhan digital grafis menyebabkan ilustrasi yang dipergunakan mempunyai daya tarik (eye catching) yang kuat; dan terakhir terletak pada kualitas resolusi gambar yang tepat sehingga majalah Bobo tampil sebagai media cetak yang artistik dan kualitas image yang tajam (high resolution).

Pendukung lain dari kekhasan ilustrasi majalah Bobo adalah selalu menampilkan nuansa tema yang berbeda dan update pada setiap terbitannya. Tema ini diilustrasikan oleh gaya busana dan tingkah laku tokoh Bobo dkk. Kadang Bobo berperan sebagai koki, kadang di edisi lain bergaya sebagai petugas dam- kar. Peran yang berganti-ganti ini secara tidak langsung menuntun pembaca untuk memahami suatu topik yang sedang hangat di media maupun lingkungan sekitarnya.

Kekhasan pada warna. Warna memegang peranan yang tidak kalah pentingnya dibandingkan dengan unsur sebelumnya. Dengan warna, sebuah sampul majalah bisa dihidupkan dan diberi predikat/ makna. Sebagai majalah anak-anak tentulah ada karakteristik warna tertentu yang patut dipakai. Warna pada majalah anak-anak tidak bisa disamakan dengan warna pada majalah orang dewasa atau manula. Warna bisa menimbulkan berbagai macam emosi seperti haru, sedih, gembira, semangat, ceria, dan lain-lain. Warna juga bisa merangsang kreativitas, kepercayaan, kenyamanan, harapan, kekuatan, ketakutan, dan lain-lain. Untuk majalah Bobo warna-warna yang diterapkan adalah warna pastel yang bernuansa cerah yang identik dengan keceriaan, kecerdasan, motivasi dan bersemangat.

Kekhasan pada teks/huruf. Ikon Bobo yang ditampilkan dengan bentuk logotype yang khas menjadikan majalah Bobo mudah dikenali diantara majalah-majalah sejenis. Huruf Bobo memang tidak dijumpai pada majalah lain karena hurufnya khusus dimodifikasi untuk judul majalah Bobo. Selain judul ada sederet teks lain yang muncul di atas sampul Bobo. Teks itu adalah kalimat tentang tagline Bobo, kalimat pada headline, dan subheadline serta beberapa kodifikasi alamat dan lain-lain. Semua unsur teks tersebut disusun oleh tidak lebih dari tiga jenis huruf yang berbeda namun dengan penataan komposisi yang tidak monoton. Kesan dinamis ini biasanya dimainkan pada tata letak headline; yang kadang berada pada posisi di bawah atau sudut, sesuai dengan harmonisasi ruang yang disediakan.

\section{PENUTUP}

\section{Simpulan}

Tampilan visual sampul majalah Bobosangat menggambarkan dunia anak-anak. Hal ini bisa dilihat dari pilihan warna, huruf, dan ilustrasi yang dipergunakan untuk mencipta- 
kan nuansa majalah anak-anak yang berkelas. Warna yang dipergunakan adalah warna pastel yang cenderung mempunyai kontras warna yang tinggi (high contrast value) sehingga mampu menciptakan nuansa dinamis, ceria, riang, cerdas, bersemangat dan dramatis sesuai dengan karakter anak-anak.

Karakter huruf/font yang dipilih jenis San Serif dan cenderung informal, dengan bentuk yang tidak terlalu kaku/ tegas agar bersesuaian dengan karakteristik anak yang bebas dan innocent. Ilustrasinya adalah karakter keluarga Bobo Kelinci dengan menampilkan peran dan kostum yang berbeda sesuai dengan tema yang diusung pada edisi yang bersangkutan, dengan gestur dan ekspresi yang mencerminkan keceriaan anak-anak yang sehat, cerdas, dan kreatif.

Unsur-unsur visual yang khas pada sampul majalah Bobo adalah terletak pada komposisinya yang harmonis dengan menerapkan prinsip kesatuan (unity), keseimbangan (balance), irama (ritme), kontras, dan proporsi. semuanya terakomodir dengan sangat baik, dengan bentuk komposisisi yang kadang simetris dan sering juga asimetris.

Daya tarik visual Bobo yang khas lainnya adalah penggunaan ilustrasi tokoh Bobo kelinci sebagai ikon utama. Sesuai dengan nama majalahnya Bobo, yang merupakan tokoh utama pada cerita Bobo Kelinci, maka penggunaan ilustrasi tokoh Bobo kelinci merupakan unsur pembeda (distinctive) antara Bobo dengan majalah anak-anak yang lain. Pendukung lain dari kekhasan majalah Bobo adalah komposisi warna pastel yang cerah ceria serta penggunaan jenis huruf yang tidak berlebihan serta tata letak teks yang menyesuaikan dengan ilustrasi.

\section{Saran}

Untuk peneliti selanjutnya, masih banyak masalah menarik yang bisa diangkat untuk mengungkapkan fakta ilmiah tentang majalah Bobo khususnya untuk penelitian yang berbasis pengembangan karakter anak. Seperti pengaruh majalah Bobo terhadap perkembangan kecerdasan visual anak, atau juga kemampuan anak mengolah pesan visual menjadi pesan verbal, dan lain-lain.

\section{UCAPAN TERIMA KASIH}

Terima kasih kepada Universitas PendidikanGaneshayangtelahmemberikankontribusi dalam penelitian, didanai dari Daftar Isian Pelaksanaan Anggaran (DIPA) UNDIKSHA.

\section{DAFTAR PUSTAKA}

Amalia, Fatwa. 2013. Kajian Nilai Moral Cerita Pendek Pada Majalah Bobo Sebagai Upaya Pemilihan Bahan Ajar Apresiasi Sastra Di Kelas Tinggi Sekolah Dasar. Skripsi. Tersedia pada http://repository.upi.edu/id/eprint/1643 (diakses 28 Maret 2016, pukul 08.25 wita).

Burton, Graeme. 2008. Yang Tersembunyi di Balik Media. Pengantar Kepada Kajian Media. Yogyakarta: Jalasutra.

Couto, Nasbahry. "Era Revolusi Digital dalam Desain Grafis untuk Mendukung Ekonomi Kreatif" (https//www.belanak. wordpress.com). Diakses tanggal 18 September 2016, pukul 11.25 wita).

Kusrianto, Adi. 2007. Pengantar Desain Komunikasi Visual. Yogyakarta: Andi Offset.

Masri, Andry. 2010. Strategi Visual. Yogyakarta: Jalasutra

Maharsi, Indiria. 2011. Komik: Dunia Kreatif Tanpa Batas. Yogyakarta: Kata Buku.

McCloud, Scout. 2001. Understandings Comics atau Memahami Komik, terjemahan S. Kinanti (2002). Jakarta: KPG.

Noerhadi, Toety Heraty. 1989. Kartun dan Karikatur sebagai Wahana Kritik Sosial. Majalah Ilmu-ilmu Sosial, XVI, No. 2.

Rakhmat, Jalaludin. 2007. Psikologi Котиnikasi. Bandung: PT. Remaja Rosdakarya.

Rustan, Surianto. 2010. Font \& Tipografi. Jakarta: PT. Gramedia Pustaka Utama

Sachari, Agus. 2007. Budaya Visual Indonesia. Jakarta: Penerbit Erlangga.

Sanyoto, Sadjiman Ebdi. Nirmana (Dasar-dasar Seni dan Desain). 2009. Yogyakarta: Jalasutra.

Sihombing, Danton. 2015. Tipografi dalam Desain Grafis. PT.GramediaPustakaUtama 
Sugiyono. 2010. Metode Penelitian Kuantitatif, Kualitatif, dan $R \& D$. Bandung: Alfabeta

Supriyono, Rakhmat. 2010. Desain Komunikasi Visual -Teori dan Aplikasi. Yogyakarta: Andi Offset.

Suryawati, Indah. 2011. Jurnalistik Suatu Pengantar. Teori dan Praktek. Jakarta: Ghalia Indonesia.

Bobo Sebagai Media Pembentukan Karakter Siswa Sekolah Dasar. Tersedia pada http:// blog.binadarma.ac.id/ayupis $/ ? \mathrm{p}=64$ (diakses pada tanggal 27 Maret 2016, pukul 16.20 wita).

Gambar Tampilan visual sampul majalah Bobo asli terbitan Belanda, dalam artikel Majalah Bobo 1973 (sampai sekarang). 2015. Tersedia pada http:// bobo. kidnesia. com/Bobo/B -Nostalgia/Kolom -Nostalgia/Sejarah-Majalah-Bobo (diakses pada tanggal 18 Maret 2016, pukul 13.53 wita).

Majalah Bobo edisi Pertama. 2013, 25 April. Tersedia pada:http://bobo.kidnesia.com/ Bobo/B-Nostalgia/KolomNostalgia/Sejarah-Majalah-Bo (diakses pada tanggal 18 Maret 2016, pukul 13.50 wita). 